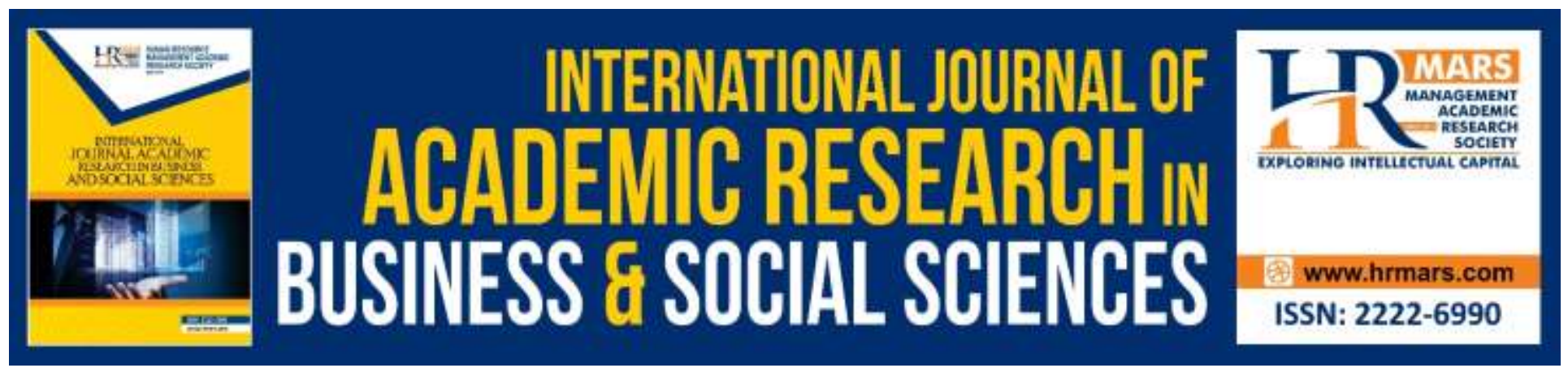

\title{
Work-related Musculoskeletal Disorders (WMSDs) Survey Among Workers at Two Precast Concrete Plants in Johor, Malaysia
}

Nor Haslinda Abas, Mohd Syahrul Syafiq Zamzam, Hairuddin Mohamad

To Link this Article: http://dx.doi.org/10.6007/IJARBSS/v10-i5/7254

DOI:10.6007/IJARBSS/v10-i5/7254

Received: 26 March 2020, Revised: 30 April 2020, Accepted: 09 May 2020

Published Online: 28 May 2020

In-Text Citation: (Abas et al., 2020)

To Cite this Article: Abas, N. H., Zamzam, M. S. S., \& Mohamad, H. (2020). Work-related Musculoskeletal Disorders (WMSDs) Survey Among Workers at Two Precast Concrete Plants in Johor, Malaysia. International Journal of Academic Research in Business and Social Sciences, 10(5), 843-856.

Copyright: (C) 2020 The Author(s)

Published by Human Resource Management Academic Research Society (www.hrmars.com)

This article is published under the Creative Commons Attribution (CC BY 4.0) license. Anyone may reproduce, distribute, translate and create derivative works of this article (for both commercial and non-commercial purposes), subject to full attribution to the original publication and authors. The full terms of this license may be seen at: $\underline{\text { http://creativecommons.org/licences/by/4.0/legalcode }}$

Vol. 10, No. 5, 2020, Pg. 843 - 856

http://hrmars.com/index.php/pages/detail/IJARBSS

JOURNAL HOMEPAGE

Full Terms \& Conditions of access and use can be found at http://hrmars.com/index.php/pages/detail/publication-ethics 


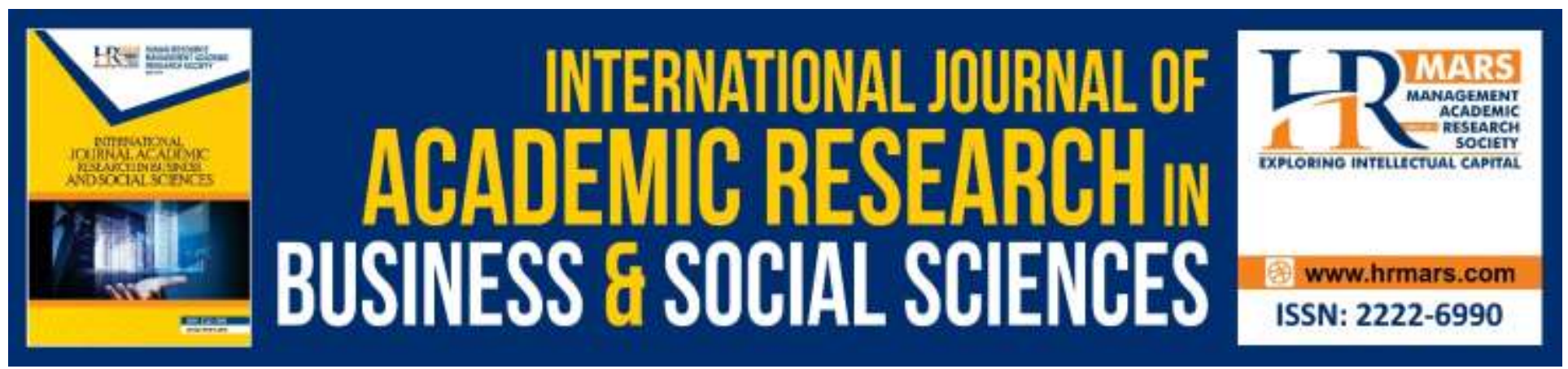

\title{
Work-related Musculoskeletal Disorders (WMSDs) Survey Among Workers at Two Precast Concrete Plants in Johor, Malaysia
}

\section{Nor Haslinda Abas, Mohd Syahrul Syafiq Zamzam¹, Hairuddin Mohamad $^{2}$}

${ }^{1}$ Jamilus Research Centre, Faculty of Civil Engineering and Built Environment, Universiti Tun Hussein Onn Malaysia, 86400 Batu Pahat, Johor, Malaysia, ${ }^{2}$ Hairuddin Mohamad, Centre for Diploma Studies, Universiti Tun Hussein Onn Malaysia, Pagoh Higher Education Hub, KM1, Jalan Panchor, 84600 Pagoh, Muar, Johor, Malaysia

Email:nhaslin@uthm.edu.my

\begin{abstract}
Work-related musculoskeletal disorders (WMSDs) are a common health problem among workers in the manufacturing industry. Construction workers tend to experience neck pain, lower back pain, knee pain, leg fatigue, and feet discomfort due to the nature of their occupation. This study aims to investigate the work-related musculoskeletal disorders (WMSDs) among workers in a precast concrete fabrication yard. Field observation was conducted at two precast concrete plants to identify the activities that potentially cause WMSD. Next, surveys were carried out on 21 workers at the selected plants to identify the area and causes of pain and discomfort, the types of treatment received by the workers, and the recovery duration for pain and discomfort, using a modified Nordic Musculoskeletal Questionnaire (NMQ) survey form. The findings show a discrepancy in the results of 2 plants. Based on the survey, the worker commonly experienced upper back pain after performing work at both plants. The workers preferred massage and rest to treat the pain. The workers would normally recover in around a week. This study will help employers discover the status of workers' WMSDs and further provide the best strategies or control measures to reduce the effect of WMSDs among their employees while at work.
\end{abstract}

Keywords: Work-related Musculoskeletal Disorders, WMSDs, Precast Concrete Plant, NMQ Survey, Body Symptom Survey, Ergonomic.

\section{Introduction}

The construction industry has the highest statistics of accidents and injuries on-site and is considered one of the riskiest businesses (Kim, 2017). The laymen perceive this industry as 'Dangerous, Difficult, and Dirty'. Today, this industry has suffered the effects of worker shortages, pervasive levels of unskilled workers, and increased labour and material costs (Kamar, 2012). To revive and to further 
improve the image of the construction industry, the Industrialised Building System (IBS) was introduced. This system introduces an innovative construction method for the industry. The IBS proposes clean site conditions and a more organised working environment to reduce Health and Safety risk (Kamar, 2010). Additionally, better safety outcomes could also be achieved by imposing fewer on-site personnel, thereby reducing hazard exposure. The IBS construction method also reduces work at a height such as from scaffoldings. Health and safety are purported to be easier to control in a factory (Kamar, 2010).

IBS is defined as a construction technique in which components are manufactured in a controlled environment (on or off-site), and then transported, positioned, and installed onto a structure with minimal additional site works (CIDB, 2003). The adoption of IBS to replace certain construction activities in fabrication yards can be termed 'industrialisation' (CRC Construction Innovation, 2007)(CRC Construction Innovation, 2007). This initiative is expected to improve health and safety performance. In Malaysia, according to the DOSH accident statistic report 2019 (up to October), although the manufacturing industry recorded the highest number of accidents

in that year (4070 out of 65622 industrial accidents), the fatality rate, particularly in construction, was lower (DOSH, 2019).

Many studies have reported better accident statistics in the manufacturing industry than the construction industry. Feyer et al. (2001) compared the extent, distribution, and nature of fatal occupational injuries in three countries (New Zealand, Australia, and the United States) between 1985 and 1994. They found that the rates of fatally injured persons (per 100,000 workers) in construction was more than three times that of manufacturing in each country. This study indicates that the manufacturing industry can be considered safer than the construction industry. Hence, it may be worthwhile applying manufacturing concepts to the construction industry. However, an issue arises regarding the reliability of the above accident statistics because manufacturing sectors are quite varied, and are not just confined to the manufacture of off-site products for construction. Despite this limitation, it is still useful to implement manufacturing concepts in the construction industry, as, in the latter, the work is done in a controlled environment, where hazards can better be controlled, and the workers are not subject to adverse environmental conditions as much.

Rwamamara (2007) argued that the transferring of on-site activities into factories did not remove the manual handling works required in on-site construction work. Additionally, changing the construction process to the factory also caused additional risks such as awkward postures and heavylifting activities. IBS prefabrication yards in Malaysia still involve intensive labour in manual tasks, which could cause work-related musculoskeletal disorders (WMSDs). For example, Kim et al. (2011) investigated a panelised construction factory in the United States to measure the ergonomic risks workers are exposed to, and found that the workers had a high risk of getting WMSD on the back. Besides, 77\% of the total measurement of shear force on the workers' backs exceeded the limit of physical capacity (Kim, 2017). In addition, Rwamamara's (2007) study on inner walls panel installation indicated high-risk partly through the heavy lifting and repetitive tasks required to set up the inner wall. Rwamamara (2007) subsequently highlighted the importance of measuring the interaction between the workers' physical capacity and the work tasks, as well as tool usage, via ergonomic analysis. To prevent or minimise the effect of WMSDs, it is essential to assess workers' exposure to WMSD risk factors and further conduct ergonomic risk assessment for the critical tasks (David, 2015; Bao et al. 2006; Andrew et al. 1998). 
However, before conducting a workplace ergonomic risk assessment, it is essential to focus on Work-related Musculoskeletal Disorders (WMSDs) among workers at the start, so that the findings from such a study can provide awareness to the employers of the current state of workers' health (particularly due to MSDs). Eventhough there are several studies related to ergonomic risk among workers in Malaysian construction industry such as Halim et al. (2012); Nazri et al. (2018); Lop et al. (2019); Muktar et al. (2017); Ahankoob \& Charehzehi (2013); Daruisiet al. (2019), there is no study existed to investigate the WMSDs exposure among workers in IBS fabrication yards in Malaysia. Therefore, this seeks to assess the WMSDs among workers in selected activities involved in the manufacturing of IBS precast concrete components by using the Nordic Musculoskeletal Questionnaire (NMQ). In order to achieve the aim, two objectives have been highlighted, as follows:

- $\quad$ to identify the critical activities at IBS precast concrete fabrication yards that expose workers to high WMSDs; and

- $\quad$ to investigate the effect of work-related musculoskeletal disorders (WMSDs) among workers at IBS fabrication yards.

The findings from this study could be utilized to formulate appropriate risk controls to prevent or reduce the occurrence and development of MSDs and among industry workers in Malaysia. Besides that, it could also provide a baseline for future ergonomic research in fabrication yards and other industries.

\section{Method}

\section{Subject and task duration}

Two precast concrete manufacturing plants in Johor were selected for the field study, as shown in Table 1. A walkthrough observation was done at both plants to identify the manufacturing activities of precast concrete components that could cause WMSDs among the workers. The activities selected for the ergonomics assessment are: i) setting up of cage reinforcement, ii) concreting and finishing, and iii) demoulding.

Table 1: Location of field study

\begin{tabular}{ccccc} 
No. & $\begin{array}{c}\text { Precast } \\
\text { concrete plant }\end{array}$ & Location & $\begin{array}{c}\text { Task duration } \\
\text { (hours per day) }\end{array}$ & $\begin{array}{c}\text { Days of work } \\
\text { (days per week) }\end{array}$ \\
1. & Plant A & Johor & 8 & $5-6$ \\
2. & Plant B & Johor & 8 & $5-6$ \\
\hline
\end{tabular}

Twenty-one workers from both plants were randomly selected as the subjects for this study, as shown in Table 2. The workers from both plants started work at $8.00 \mathrm{a} . \mathrm{m}$. and finished at $5.00 \mathrm{p} . \mathrm{m}$. Within these working hours, the workers were provided with breaks and rest between 10.00 a.m. to 10.30 a.m., 1.00 p.m. to 2.00 p.m., and 3.15 p.m. to 3.30 p.m. Sometimes, the workers would also work overtime until 9.00 p.m. (with breaks from 5.00 p.m. to 7.00 p.m.) due to high demand. 
INTERNATIONAL JOURNAL OF ACADEMIC RESEARCH IN BUSINESS AND SOCIAL SCIENCES

Vol. 10, No. 5, May, 2020, E-ISSN: 2222-6990 @ 2020 HRMARS

Table 1: Subject details

\begin{tabular}{|c|c|c|c|}
\hline \multirow{2}{*}{ No. } & Activity & \multicolumn{2}{|c|}{ Number of subjects } \\
\cline { 3 - 4 } & & Plant 1 & Plant 2 \\
\hline 1 & Setting up a reinforcement cage & 4 & 4 \\
\hline 2 & Concreting and finishing & 3 & 3 \\
\hline 3 & Demoulding & 3 & 4 \\
\hline & Total & $\mathbf{1 0}$ & $\mathbf{1 1}$ \\
\hline
\end{tabular}

Nineteen (19) workers had been doing the work activities between 1 and 5 years, while the remaining 2 workers had more than 5 years of working experience. About 8 workers were between 18 and 25 years old, 8 workers were 36 to 33 years old, 4 workers were $34-41$ years old, and 1 worker was over 41 years old.

\section{Survey}

This study adopted the methods of Halim et al. (2012) and Nazri et al. (2018) for assessing WMSDs among workers, i.e., using a survey form. Two types of questionnaires were used in this study-a general questionnaire and a specific questionnaire. The Nordic Musculoskeletal Questionnaire (NMQ) was designed to include general questions to determine the common problem, such as the parts of the body that experience MSDs. For example, Figure 1 shows the back view of the human body, which is divided into nine (9) regions. The respondents need to select the region that is experiencing MSD symptoms. On the other hand, the specific questionnaire consists of special questions that can be used to analyse the severity of the symptoms in more depth. This questionnaire provides useful information that would help formulate MSD preventive measures. The researchers brought the survey forms to the selected construction sites and directly interviewed the workers to acquire their responses to the survey form. 
INTERNATIONAL JOURNAL OF ACADEMIC RESEARCH IN BUSINESS AND SOCIAL SCIENCES

Vol. 10, No. 5, May, 2020, E-ISSN: 2222-6990 @ 2020 HRMARS

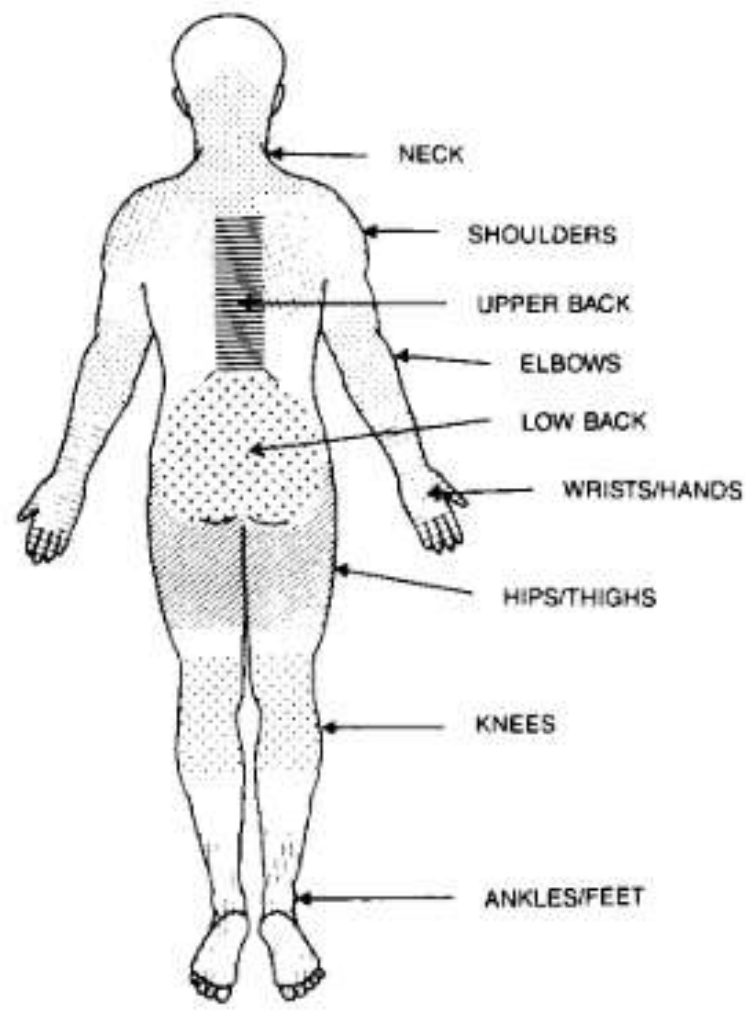

Figure 1: Human Body Parts (Source: Kuorinka et al. 1987)

\section{Results of the Survey}

\section{Area of Pain or Discomfort after Performing Works}

Table 3 shows the number of complaints in the areas of pain or discomfort. The analysis of the survey revealed that the workers in Plant 1 had more complaints of pain or discomfort in body areas for each selected activity, compared to those in Plant 2. The workers who set up the reinforcement cage for each plant had the highest of complaints. The workers noted pain or discomfort, mostly on the upper back, lower back, shoulders, and wrists/hands. None complained about pain in the neck area, while a very few complaints were received for elbow and hips/thigh pain. 
INTERNATIONAL JOURNAL OF ACADEMIC RESEARCH IN BUSINESS AND SOCIAL SCIENCES Vol. 10, No. 5, May, 2020, E-ISSN: 2222-6990 @ 2020 HRMARS

Table 3: Number of complaints according to the area of pain or discomfort after performing works

\begin{tabular}{|c|c|c|c|c|c|c|c|c|c|c|c|}
\hline \multirow[b]{2}{*}{ Activity } & \multirow{2}{*}{ 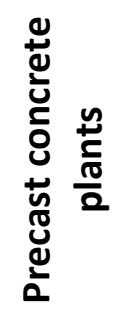 } & \multicolumn{10}{|c|}{ Area of pain or discomfort after performing works } \\
\hline & & 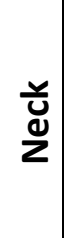 & $\frac{\frac{n}{d}}{\frac{0}{3}}$ & $\begin{array}{l}n \\
\vdots \\
0 \\
\bar{u}\end{array}$ & 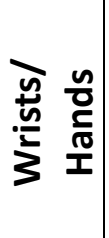 & 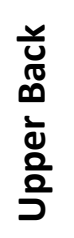 & $\begin{array}{l}\text { U } \\
\text { D } \\
0 \\
\frac{1}{0} \\
3 \\
0\end{array}$ & 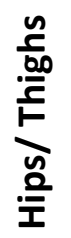 & 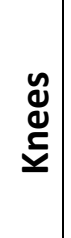 & 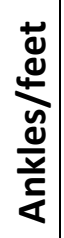 & 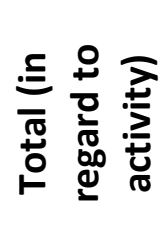 \\
\hline \multirow{2}{*}{$\begin{array}{l}\text { Set up } \\
\text { reinforcement } \\
\text { cage }\end{array}$} & $\begin{array}{c}\text { Plant } \\
1\end{array}$ & 0 & 1 & 0 & 1 & 4 & 4 & 3 & 3 & 4 & 19 \\
\hline & $\begin{array}{c}\text { Plant } \\
2\end{array}$ & 0 & 1 & 0 & 4 & 3 & 2 & 0 & 1 & 1 & 12 \\
\hline \multirow{2}{*}{$\begin{array}{l}\text { Concreting } \\
\text { and finishing }\end{array}$} & $\begin{array}{c}\text { Plant } \\
1 \\
\end{array}$ & 0 & 2 & 0 & 0 & 4 & 4 & 0 & 0 & 0 & 10 \\
\hline & $\begin{array}{c}\text { Plant } \\
2\end{array}$ & 0 & 1 & 1 & 2 & 3 & 1 & 0 & 0 & 0 & 8 \\
\hline \multirow{2}{*}{ Demoulding } & $\begin{array}{c}\text { Plant } \\
1 \\
\end{array}$ & 0 & 2 & 0 & 2 & 3 & 3 & 0 & 0 & 1 & 11 \\
\hline & $\begin{array}{c}\text { Plant } \\
2\end{array}$ & 0 & 3 & 0 & 1 & 2 & 1 & 0 & 1 & 0 & 8 \\
\hline \multicolumn{2}{|c|}{$\begin{array}{c}\text { Total (in regard to } \\
\text { body area) }\end{array}$} & 0 & 10 & 1 & 10 & 19 & 15 & 3 & 5 & 6 & \\
\hline
\end{tabular}

\section{Causes of Pain or Discomfort among Workers}

Figure 2 shows the causes of pain or discomfort among the workers from both plants. The findings indicate the highest frequency for the causes of pain or discomfort for every activity at each plant. The workers suffered pain or discomfort in certain body areas due to work demands, such as the manipulation of heavy loads, high force exertion, awkward working postures, static loading, and repetitive works. The results show that awkward postures were the most common cause of pain or discomfort. It is also the cause reported for each activity in each plant. None of the workers mentioned static loading as the main cause of pain or discomfort for an activity. The workers from Plant 2 reported high force exertion in setting up the reinforcement cage and concreting and vibrating activities as the contributing cause of pain and discomfort.

From Figure 2, it can be seen that the causes of pain or discomfort varied between Plant 1 and Plant 2. 
INTERNATIONAL JOURNAL OF ACADEMIC RESEARCH IN BUSINESS AND SOCIAL SCIENCES Vol. 10, No. 5, May, 2020, E-ISSN: 2222-6990 @ 2020 HRMARS

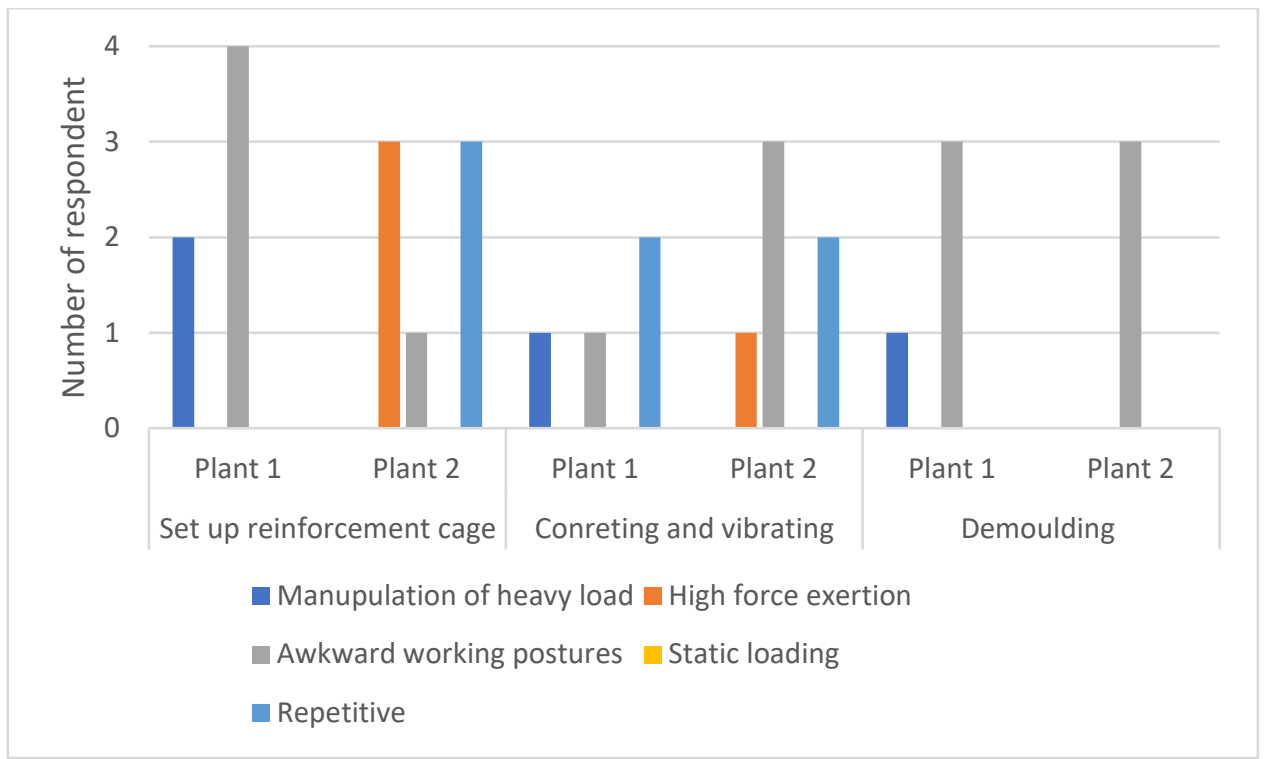

Figure 2. Causes of pain or discomfort among workers

\section{Types of Treatment for Pain Recovery}

The data was analysed to determine the type of treatment to reduce pain or discomfort among the workers. The workers mentioned several types of treatment, such as taking medicine, massage, and rest. The result shows that most of the respondents from Plant 1 chose 'medicine' as the preferred treatment to reduce the effects of WMSDs. Meanwhile, most of the respondents from Plant 2 chose 'rest'. The respondents from Plant 1 and Plant 2would also go for a 'Massage' to recover from 'setting up the reinforcement cage'. The analysis also revealed that some respondents mixed the types of treatment to reduce pain or discomfort faster. The results of this study are in-line with a previous study, which also found medicine as the preferred choice of treatment [4]. This result might be due to the types of treatment provided by the company, where the workers tend to use medicine because it is provided for and accessible at the workplace. If no medicine was provided, the workers might just rest to recover from the pain or discomfort. In conclusion, the workers from both precast concrete plants chose different treatments to reduce their pain or discomfort, depending on their preferences. 
INTERNATIONAL JOURNAL OF ACADEMIC RESEARCH IN BUSINESS AND SOCIAL SCIENCES Vol. 10, No. 5, May, 2020, E-ISSN: 2222-6990 @ 2020 HRMARS

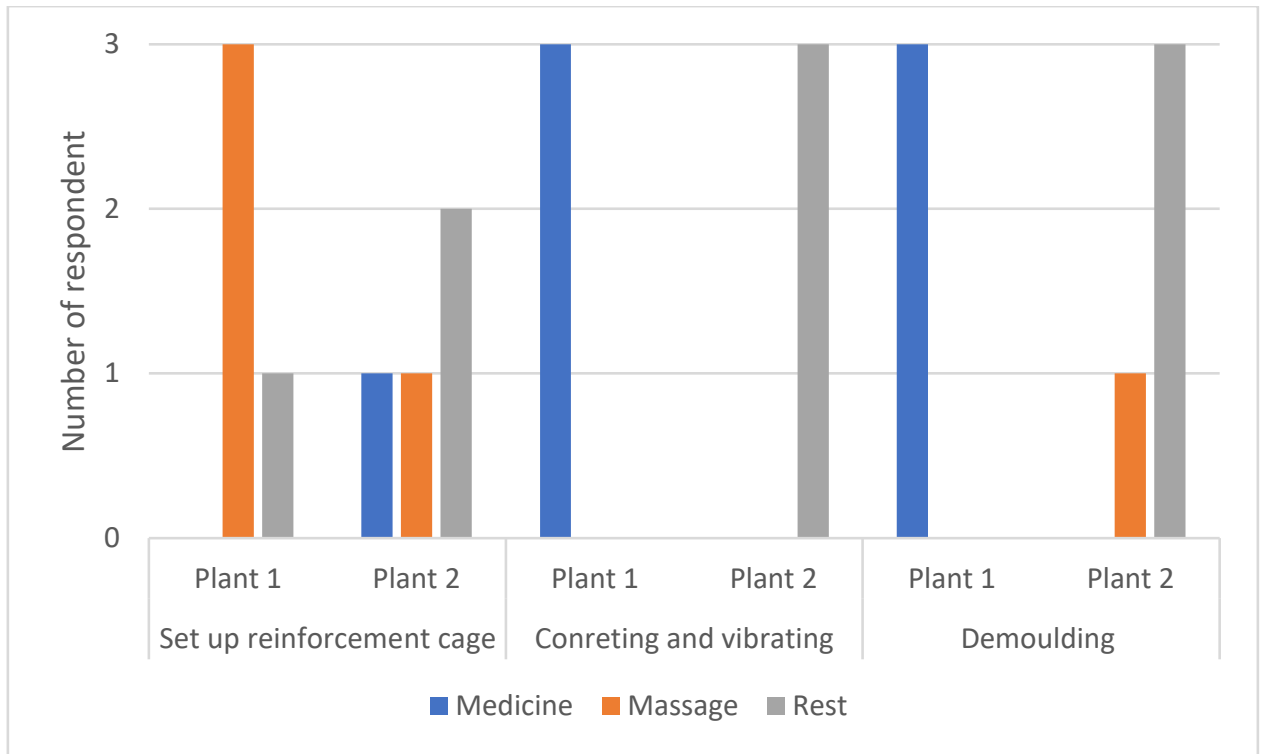

Figure 3. Types of treatment for pain or discomfort

\section{Recovery Duration for Pain or Discomfort}

This study also identified the time it took for the workers to recover from the pain, whether 0 days, 1-7 days or 8-30 days. Zero days means that the workers took less than 24 hours to recover from the musculoskeletal disorder while 1-7 days means the workers took about less than a week to recover from the musculoskeletal disorder. The recovery duration for pain or discomfort among the respondents is shown in Figure 4. Most of the respondents from Plant 1 recovered in 1-7 days, whereas the majority of the respondents in Plant 2 recovered in 0 days. None of the respondents took more than 8 days to recover from pain or discomfort.

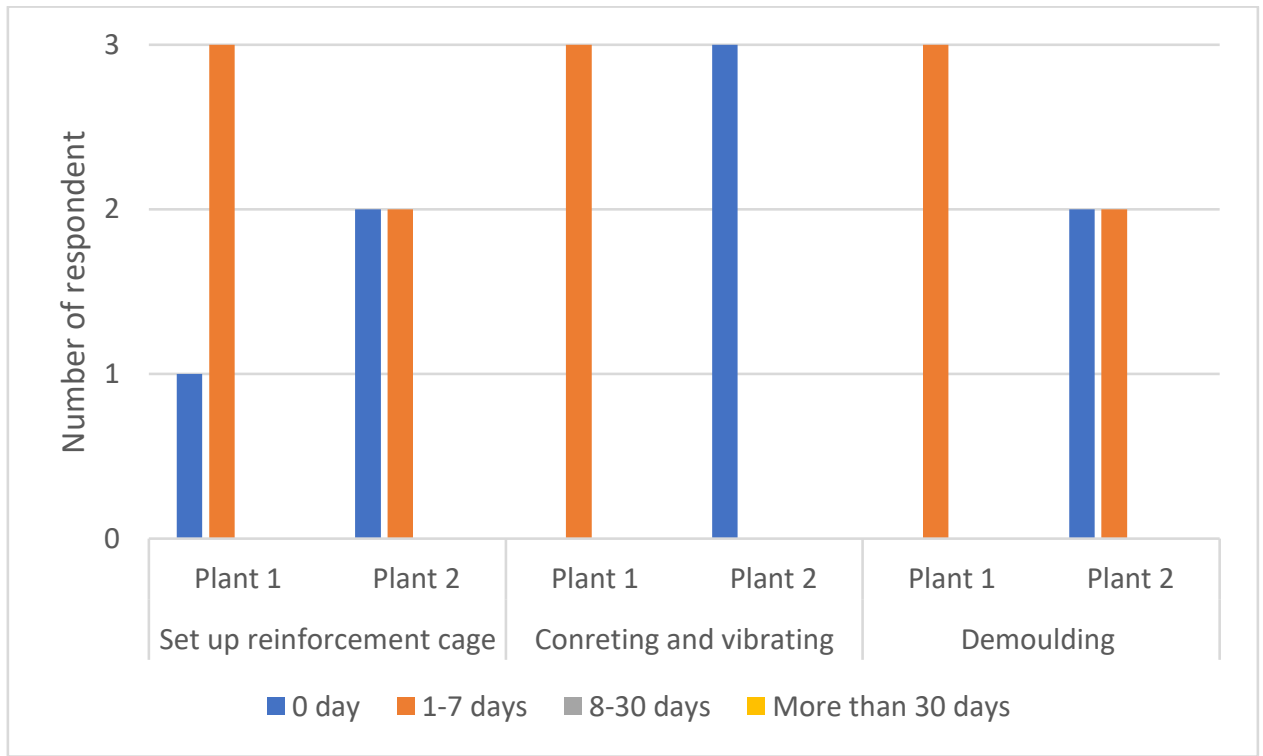

Figure 4. Recovery duration for workers in demoulding activity 


\section{Discussion and Conclusion}

This study was conducted to identify the activities at IBS precast concrete fabrication yards that expose workers to highly WMSDs and to investigate the effect of work-related musculoskeletal disorders (WMSDs) among workers at IBS fabrication yards. Two (2) precast concrete fabrication yards were selected as case studies, which involved collecting the WMSDs data of several workers for setting up reinforcement cage, concreting and vibrating, and demoulding at each fabrication yards. Table 4 shows a summary of the NMQ result survey, indicating the highest frequency of results for each question. The areas of pain or discomfort were due to several causes such as the manipulation of heavy loads, high force exertion, awkward working postures, static loading, and repetitive works. The critical areas of pain or discomfort were the ankles/feet, wrists/hands, shoulder, upper back, and lower back for both precast concrete plants. The workers cited awkward working postures, high force exertion and repetitive work while performing the critical activities as the main causes of pain or discomfort. The workers preferred to rest, go for a massage, or take medicine to treat or reduce their musculoskeletal disorders. The workers from both precast concrete plants took about less than a week to recover from the pain or discomfort. Overall, the workers in Plant 1 had more critical musculoskeletal disorders than those in Plant 2. 
Table 4: A summary of the NMQ results

\begin{tabular}{|c|c|c|c|c|c|}
\hline Activity & $\begin{array}{l}\text { Precast } \\
\text { Plant }\end{array}$ & $\begin{array}{l}\text { Highest frequency } \\
\text { of area of pain or } \\
\text { discomfort }\end{array}$ & $\begin{array}{l}\text { Highest reported } \\
\text { causes of pain or } \\
\text { discomfort }\end{array}$ & $\begin{array}{l}\text { Most } \\
\text { preferabl } \\
\text { e types } \\
\text { of } \\
\text { treatmen } \\
t\end{array}$ & $\begin{array}{l}\text { Highest } \\
\text { reported } \\
\text { recovery } \\
\text { duration }\end{array}$ \\
\hline \multirow[t]{2}{*}{$\begin{array}{l}\text { Set up cage } \\
\text { einforcement }\end{array}$} & Plant 1 & $\begin{array}{l}\text { 1) } 4 \text { complaints on } \\
\text { upper back } \\
\text { 2) } 4 \text { complaints on } \\
\text { lower back } \\
\text { 3) } 4 \text { complaints on } \\
\text { ankle/feet }\end{array}$ & $\begin{array}{l}4 \text { cases reported } \\
\text { due to awkward } \\
\text { working postures }\end{array}$ & Massage & $1-7$ days \\
\hline & Plant 2 & $\begin{array}{l}\text { 1) } 4 \text { complaints on } \\
\text { wrist/ } \\
\text { hands }\end{array}$ & $\begin{array}{l}3 \text { cases reported } \\
\text { due to high force } \\
\text { exertion and } \\
\text { repetitive }\end{array}$ & Rest & $\begin{array}{c}0 \text { day and } 1- \\
7 \text { days }\end{array}$ \\
\hline \multirow{2}{*}{$\begin{array}{l}\text { Concreting } \\
\text { and vibrating }\end{array}$} & Plant 1 & $\begin{array}{l}\text { 1) } 4 \text { complaints on } \\
\text { upper back } \\
\text { 2) } 4 \text { complaints on } \\
\text { lower back }\end{array}$ & $\begin{array}{l}2 \text { cases reported } \\
\text { due to repetitive }\end{array}$ & Medicine & $1-7$ days \\
\hline & Plant 2 & $\begin{array}{l}\text { 1) } 3 \text { complaints on } \\
\text { upper back }\end{array}$ & $\begin{array}{l}3 \text { cases reported } \\
\text { due to awkward } \\
\text { working postures }\end{array}$ & Rest & 0 day \\
\hline \multirow[t]{2}{*}{ Demoulding } & Plant 1 & $\begin{array}{l}\text { 1) } 3 \text { complaints on } \\
\text { upper back } \\
\text { 2) } 3 \text { complaints on } \\
\text { lower back }\end{array}$ & $\begin{array}{l}3 \text { cases reported } \\
\text { due to awkward } \\
\text { working postures }\end{array}$ & Medicine & $1-7$ days \\
\hline & Plant 2 & $\begin{array}{l}\text { 1) } 3 \text { complaints on } \\
\text { shoulder }\end{array}$ & $\begin{array}{l}3 \text { cases reported } \\
\text { due to awkward } \\
\text { working postures }\end{array}$ & Rest & $\begin{array}{c}0 \text { day and } 1- \\
7 \text { days }\end{array}$ \\
\hline
\end{tabular}

The results of the overall body symptoms survey of all the respondents (10 staffs) are shown in Figure 4. The percentage shown in Figure 4 shows the percentage of respondents that reported experiencing aches, pain, and discomfort in that particular region. From this figure, it can be seen that the respondents in Plant 1 reported experiencing the most pain and discomfort on their upper back, lower back, shoulders, and ankle/feet for, while the respondents from Plant 2 experienced the most pain in the upper back and wrists/hands. The results also show that the workers in Plant 2 experienced more pain or discomfort than those in Plant 2. This result could be due to the working position and the design of the work. For example, the workers in Plant 1 experienced pain on the back because the casting bed is placed at the hip/thigh level, so the workers must be in extremely bent-forward position during concreting and vibrating, as well as demoulding. Extreme bending was also required during the setting up the reinforcement cage.

Instead of relying on treatment and medications, the authors had proposed several corrective actions to be undertaken by the employers. The proposed recommendations were discussed with 
the production managers, engineers and supervisors at both fabrication yards. Such recommended measures are job rotation, regular short breaks in between formal breaks, and training on ergonomics which covers the topics such as work practices, correct posture, health examinations and follow up measures, and mini exercises. Other than that, the employers can also implement engineering controls such as re-designing of work station and modifyingthe exiting tools and equipment. As most of the ergonomic problems were caused by poorly designed job tasks, adopting engineering controls are more favorable to effectively reduce ergonomic hazard exposures among workers (Muktar et al., 2017). The job task or equipment could be altered to facilitate the task and to reengineer it such that it falls within the workers' limitations (Amell and Kumar, 2001). Additionally, it is desirable to use assessment tools that can predict the risk of future WMSDs. In so doing, monetary costs and human suffering can be averted via remediation efforts (Hamrick, 2006). Furthermore, improvements to workplace ergonomics should be investigated. The design principles and existing industry best practices may also be applied to prevent, eliminate, or reduce WMSD risk factors (Rwamamara, 2005).

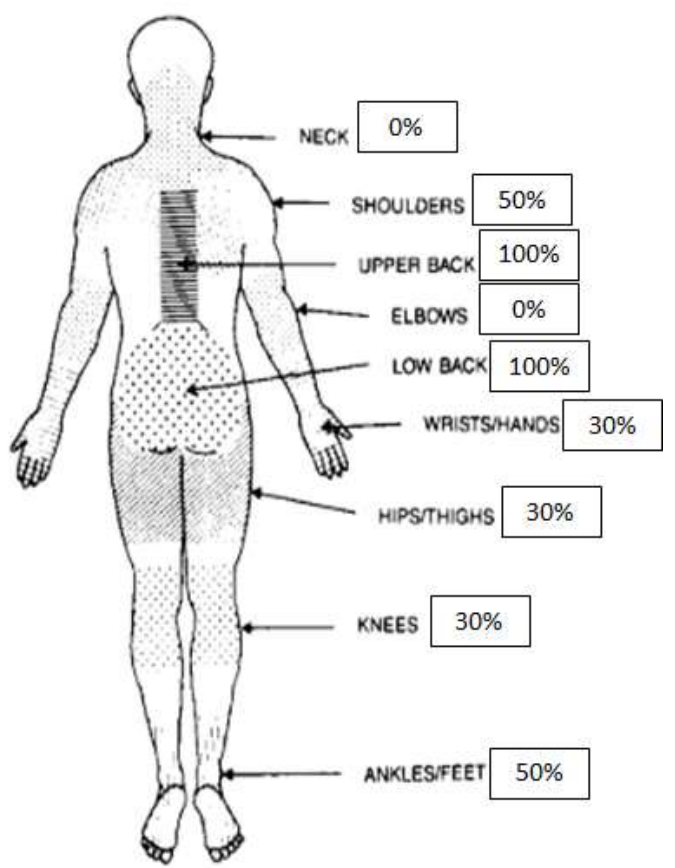

(a)

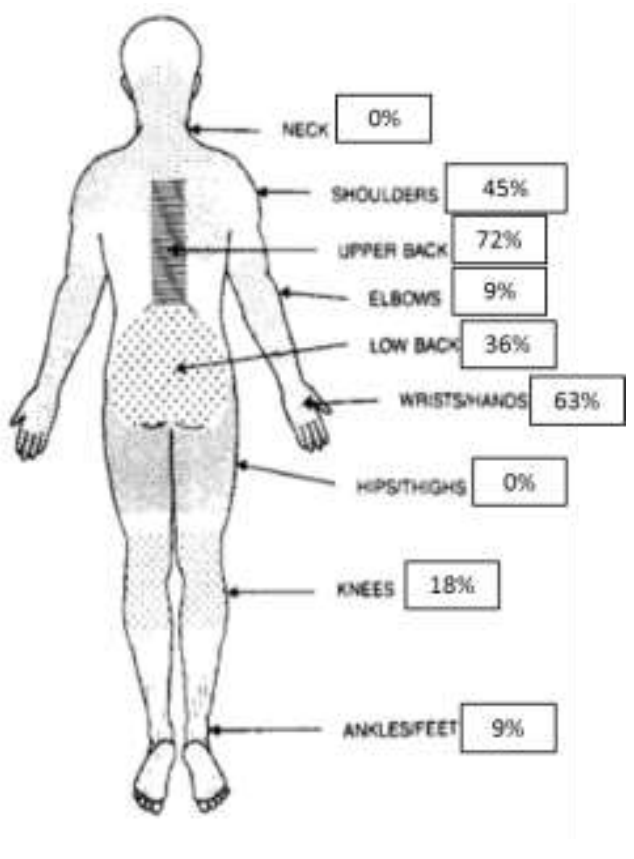

(b)

Figure 5: Prevalence of musculoskeletal discomfort among workers from (a) Plant 1; (b) Plant 2

The researchers recommend further study to assess the exposure to WMSD risk factors among workers in precast concrete plants. This can be done by identifying the ergonomic risk factors that expose employees to potential MSDs, back pain and discomfort. Based on the findings of ergonomic risk assessment, the ergonomic scores on the degree of ergonomic risks that employees are being exposed to while performing identified tasks can be provided and highlighted to the management. Such a study is vital, as these plants represent an essential stage in the management and prevention of WMSDs (David, 2005).

In conclusion, reducing the WMSDs could prevent reduction of working performances, demotivation to work extra hours and absenteeism among workers. Therefore, both employers and 
INTERNATIONAL JOURNAL OF ACADEMIC RESEARCH IN BUSINESS AND SOCIAL SCIENCES Vol. 10, No. 5, May, 2020, E-ISSN: 2222-6990 @ 2020 HRMARS

employees should always enhance their knowledge on ergonomics to improve their awareness so that WMSDs complaints among workers can be reduced. The findings of the study serves as a basis for or a stepping stone towards an in- depth study on the WMSDs among workers in IBS fabrication yard and other realted industry. This would assist employers to plan, implement and monitor the preventive measures undertaken, despite reduction of ergonomics-related injuries and MSDs, as well as reduction of compensation cost and medical expenses.

\section{Acknowledgement}

The authors would like to thank the Research Fund E15501, Research Management Centre, Universiti Tun Hussein Onn Malaysia for supporting this research.

\section{References}

Ahankoob, A., \& Charehzehi, A. (2013). Mitigating ergonomic injuries in construction iindustry. IOSR Journal of Mechanical and Civil Engineering, 6(2), 36-42.

Amell, T., \& Kumar, S. (2001). Work-Related Musculoskeletal Disorders: Design as a Prevention Strategy, A review. Journal of Occupational Rehabilitation, 11(4), 255-265.

Andrews, D. M., Norman, R. W., Wells, R. P., \& Neumann, P. (1998). Comparison of self-report and observer methods for repetitive posture and load assessment. Occupational Ergonomics, 1(3), 211-222.

Bao, S., Silverstein, B., Howard, N., \& Spielholz, P. (2006). The Washington State SHARP Approach to Exposure Assessment. In W. S. Marras, \& W. Karwowski, (Eds.), The Occupational Ergonomics Handbook, Second Edition: Fundamentals and Assessment Tools for Occupational Ergonomics (pp. 44.1-22). NW Boca Raton, Florida: CRC Press.

CIDB. (2003). IBS Survey. Kuala Lumpur: Construction Industry Development Board (CIDB).

Daruisi, D. D. I., Deros, B. M., \& Jeyasekaran, N. (2019). Ergonomics risk assessment among infrastructure construction workers in Kuala Lumpur. Human Factors and Ergonomics Journal, $4(1), 32-40$.

David, G. C. (2005). Ergonomic methods for assessing exposure to risk factors for work-related musculoskeletal disorders. Occup. Med., 55(3), 190-199.

DOSH. (2019). Occupational accident statistics by sector until October 2019 (reported to DOSH only). Retrieved from https://www.dosh.gov.my/index.php/statistic-v/occupational-accidentstatistics-v/occupational-accident-statistic-2019/3352-occupational-accidents-statistics-bysector-until-october-2019-investigated/file

Feyen, R., Liu, Y., Chaffin, D., Jimmerson, G., \& Joseph, B. (2000). Computer-aided ergonomics: A case study of incorporating ergonomics analyses into workplace design. Applied Ergonomics, 31(3), 291-300.

Halim I., Abdullah R., \& Ismail, A. R. (2012). A Survey on Work-related Musculoskeletal Disorders (WMSDs) among Construction Workers. Journal of Occupational Safety \& Health, 9, 1-6.

Hamrick, C. (2006). Overview of Ergonomic Assessment. In W. S. Marras, \& W. Karwowski, (Eds.), The Occupational Ergonomics Handbook, Second Edition: Fundamentals and Assessment Tools for Occupational Ergonomics (pp. 34.1-11). NW Boca Raton, Florida: CRC Press.

Jaffar, N., \& Lop, N. S. (2011). A Literature Review of Ergonomics Risk Factors in Construction Industry. Procedia Engineering, 20, 89-97. 
INTERNATIONAL JOURNAL OF ACADEMIC RESEARCH IN BUSINESS AND SOCIAL SCIENCES

Vol. 10, No. 5, May, 2020, E-ISSN: 2222-6990 @ 2020 HRMARS

Kamar, K. A. M., Abd Hamid, Z., \& Dzulkalinine, N. (2012). Industrialised Building System (IBS) construction: Measuring the perception of contractors in Malaysia, 2012 IEEE Business, Engineering \& Industrial Applications Colloquium (BEIAC), Kuala Lumpur, pp. 328-333, doi: 10.1109/BEIAC.2012.6226077

Kamar, K. A. M. (2010). The critical success factors and readiness of contractors in adopting Industrialised Building System (IBS) construction (PhD Thesis). University of Salford, Manchester, England.

Kim, I. J. (2017). The Role of Ergonomics for Construction Industry Safety and Health Improvements. Journal of Ergonomics, 7(2), 2-5.

Kuorinka, I., Jonsson, B., Kilbom, A., Vinterberg, H., Biering-Sørensen, F., Andersson, G., \& Jørgensen, K. (1987). Standardised Nordic questionnaires for the analysis of musculoskeletal symptoms,.Applied Ergonomics, 18(3), 233-237.

Lop N. S., Mat Salleh, N., Yop Zain, M. F., \& Saidin, M. T. (2019). Ergonomic Risk Factors (ERF) and their Association with Musculoskeletal Disorders (MSDs) among Malaysian Construction Trade Workers: Concreters. International Journal of Academic Research in Business and Social Sciences, 9(9), 1269-1282.

Muktar, M. Z., Shamsudin, S. B., Awang Lukman, K. \& Jeffree, M. S. (2017). Assessment of ergonomic risk and working performance of pre-cast construction workers in Sabah. Malaysian Journal of Public Health Medicine, 17(2), 151-158.

Nazri, M. I. A., Abas, N. H., Mohd Affandi, H., Deraman, R., Hasmori, M. F., Abas, N. A. \& Mustaffa Kamal, M. F. (2018). A survey on work-related musculoskeletal disorders (WMSDs) among construction trades. International Journal of Integrated Engineering, 10(4), 131-139.

Rwamamara, R. A. (2007). Risk assessment and analysis of workload in an industrialised construction process. Construction Information Quarterly, 9(2), 80-85. 